\title{
Effect of Pediatric Toothpastes Based on 500 to 1450 ppm Sodium Fluoride and Amine Fluoride with Different Detergents on Oxidative Stress and Cell Viability
}

\author{
500-1450 ppm Sodyum Florür ve Amin Florür Bazlı, Farklı Deterjan \\ Içerikli Pediatrik Diş Macunlarının OksidatifStres ve Hücre Canlıığı \\ Üzerine Etkisi
}

(1) Firdevs Kahvecioğlu¹, (1) Hayriye Esra Ülker2, (1) Gül Tosun ${ }^{1}$, (1) Mutlu Özcan³

1 Selçuk University Faculty of Dentistry, Department of Pediatric Dentistry, Konya, Turkey

${ }^{2}$ Selçuk University Faculty of Dentistry, Department of Restorative Dentistry, Konya, Turkey

3University of Zürich, Division of Dental Biomaterials, Center for Dental and Oral Medicine, Clinic for Reconstructive Dentistry, Zürich, Switzerland

Keywords

Cytotoxicity, pediatric dentistry, reactive oxygen species, toothpaste

Anahtar Kelimeler

Sitotoksisite, pediatrik diş hekimliği, reaktif oksijen ürünleri, diş macunu

Received/Geliş Tarihi : 10.03.2021

Accepted/Kabul Tarihi : 31.08.2021

doi:10.4274/meandros.galenos.2021.65982

Address for Correspondence/Yazışma Adresi: Firdevs Kahvecioğlu Ph.D.,

Selçuk University Faculty of Dentistry, Department of Pediatric Dentistry, Konya, Turkey

Phone : +90 3322231290

E-mail : drfirdevskahveci@hotmail.com

ORCID ID: orcid.org/0000-0003-4216-0849

(C) Meandros Medical and Dental Journal, Published by Galenos Publishing House.

This is article distributed under the terms of the

Creative Commons Attribution NonCommercial 4.0

International Licence (CC BY-NC 4.0).

\begin{abstract}
Objective: This study evaluated the effect of sodium fluoride and amine fluoride pediatric toothpastes with different detergents on oxidative stress and cell viability. Materials and Methods: Pediatric toothpastes containing sodium fluoride (Sensodyne Pronamel-SP; Ipana Kids-IK; Signal Kids-SK; Oral B-OB) and amine fluoride (Elmex-EL; Elmex Junior-EJ) were obtained. While SP, IK, EL contained cocamidopropyl betaine detergent, SK, OB sodium lauryl sulfate and EJ had olaflur detergents. Toothpaste samples were diluted with medium at different predetermined concentrations. L929 fibroblast cells were exposed to toothpaste extracts at $37^{\circ} \mathrm{C}$ for $2 \mathrm{~min}$. Cell viability was tested using methyl tetrazolium test, while the formation of reactive oxygen species (ROS) was detected using flow cytometry.

Results: The decreasing concentration ratio from 1:1 to $1: 32$ decreased the cytotoxicity $(p<0.05)$ except EL. The cytotoxicity of original pediatric toothpaste extracts (1:1) were significantly different, compared to the negative control group $(p<0.05)$, except IK and EL ( $p>0.05)$. All toothpastes tested increased the number of ROS in L929 cells $(p<0.05)$.

Conclusion: Pediatric toothpastes containing sodium fluoride with sodium lauryl sulfate presented more cytotoxic effect.
\end{abstract}

Öz

Amaç: Bu çalışmada, sodyum florür ve amin florür içeren pediatrik diş macunlarının farklı deterjan içeriklerinin oksidatif stres ve hücre canlılığı üzerine etkisi değerlendirilmiştir.

Gereç ve Yöntemler: Sodyum florür (Sensodyne Pronamel-SP; Ipana Kids-IK; Signal Kids-SK; Oral B-OB) ve amin florür (Elmex-EL; Elmex Junior-EJ) içeren pediatrik diş macunları kullanıldı. SP, IK, EL kokamidopropil betain deterjan içerirken, SK, $\mathrm{OB}$ sodyum lauril sülfat ve EJ olaflur deterjan içerikliydi. Diş macunu numuneleri önceden belirlenmiş farklı konsantrasyonlarda medyum ile seyreltildi ve $\mathbf{L 9 2 9}$ fibroblast hücreleri, diş macunu ekstraktlarına $37^{\circ} \mathrm{C}$ 'de 2 dakika maruz bırakıldı. 
Hücre canlıı̆ı̆ı metil tetrazolyum testi kullanılarak test edilirken, reaktif oksijen türlerinin oluşumu (ROS) flow sitometrisi kullanılarak tespit edildi.

Bulgular: 1:1'den 1:32'ye azalan konsantrasyon oranı, EL haricinde sitotoksisiteyi azalttı $(p<0,05)$. Orijinal pediatrik diş macunu ekstraktlarının (1:1) sitotoksisitesi, negatif kontrol grubuna $(p<0,05)$ kıyasla, IK ve EL haricinde $(p>0,05)$ önemli ölçüde farklıydı. Test edilen tüm diş macunları, L929 hücrelerindeki ROS miktarını artırdı $(p<0,05)$.

Sonuç: Sodyum florür içeren ve sodyum lauril sülfat içeren pediatrik diş macunları daha fazla sitotoksik etki göstermiştir.

\section{Introduction}

Tooth brushing using a toothpaste is an important oral hygiene practice that is beneficial for dental and gingival health, aids dental plaque removal, and prevents dental caries, especially in children (1). Toothpastes generally comprise abrasive, surfaceactive, moisturizing, gelling and/or binding, flavoring, preservative, and staining agents; sweeteners; and fluorides (2). The ideal toothpaste for children should comprise ingredients compatible with fluoride delivery to ensure adequate fluoride availability, minimal abrasivity, and consequently, a pleasant brushing experience $(1,2)$.

The efficacy of fluoride-containing toothpastes depends on their fluoride concentration, frequency of use, volume of toothpaste used, and rinsing habits after brushing (3). Children between the ages of two-four and five-seven years swallow 34\% and $13 \%$ toothpastes, respectively, while older children and adults ingest only 6\% (4). Therefore, dentists should be aware of the potential adverse effects of toothpastes and fluorides and counsel patients and/or parents accordingly. Since many decades, prescription of fluoride toothpastes in carefully selected patients has been effective in preventing dental caries (5). However, some toothpaste components such as detergents may be harmful because of their foaming ability (6). Sodium lauryl sulfate (SLS), which is the most commonly used detergent in mouthwashes and toothpastes, is capable of denaturing proteins (7). Short-term use of toothpastes with $\leq 2 \%$ SLS content is considered harmless (5). Cocamidopropyl betaine (CAPB) is another commonly used detergent in toothpastes. CAPB-containing toothpastes are believed to be less irritating and can alleviate symptoms of dry mouth (8). Amine fluoride (AF) in toothpastes can also act as a detergent and affects L929 fibroblast cells (9).

Limited information is available in the literature on commercially available pediatric toothpastes for children $\leq 12$ years old regarding the cytotoxic effects on gingival fibroblasts and L929 mouse fibroblasts and potential for causing oral squamous cell carcinoma $(9,10)$.

Reactive oxygen species (ROS) are generated during mitochondrial oxidative metabolism. Oxidative stress refers to the instability caused by excess ROS or oxidant production. Various chemicals can disrupt the stable cellular redox balance, resulting in increased levels of ROS and subsequent cell death through apoptosis (11).

Therefore, in this study, we evaluated the effects of sodium fluoride- and AF-based pediatric toothpastes containing different detergents on oxidative stress and cell viability. The null hypothesis was that the type of detergent in sodium fluoride- and AF-based toothpastes in different dilutions would not have a significant effect on oxidative stress and cell viability of $L 929$ murine fibroblast cells.

\section{Materials and Methods}

This study was approved by the Selçuk University Faculty of Dentistry Ethics Committee (decision no: 2015/01, date: 08.10.2015). Commercial pediatric toothpastes containing sodium fluoride (Sensodyne Pronamel-(SP), 1450 ppm; Ipana Kids-IK, 500 ppm; Signal Kids-(SK), 500 ppm; Oral B-OB, 500 ppm) and AF (Elmex-EL, 500 ppm; Elmex Junior-EJ, 1400 ppm) were obtained. SP, IK, and EL comprised CAPB; SK and OB contained SLS, and EJ comprised olaflur (Table 1).

The toothpastes were diluted in a medium (50 $w / v \%$ ), homogenized using a vortex (WisemixVM-10; Daihan Scientific Co., Ltd., Seoul, South Korea), centrifuged (Hettich 320R Centrifuge, maximum speed: 15000 rpm, Germany), filtered, and immediately used in experiments. The original extracts (1:1) were diluted at 1:2, 1:4, 1:8, 1:16, and 1:32 in the medium.

\section{Cytotoxicity Testing}

L929 cells were seeded on each well of a 96-well plate at a density of $2 \times 10^{4}$ cells/well and incubated at $37{ }^{\circ} \mathrm{C}$ for $24 \mathrm{~h}$ cultured in Dulbecco's modified Eagle's medium supplemented with $10 \%$ fetal bovine 


\begin{tabular}{|c|c|c|c|}
\hline Group & Detergent content & Fluoride content & Composition \\
\hline SP & Cocamidopropyl betaine & $\begin{array}{l}\text { Sodium fluoride } \\
1450 \text { ppm }\end{array}$ & $\begin{array}{l}\text { Aqua, sorbitol, hydrated silica, glycerin, PEG-6, cocamidopropyl } \\
\text { betaine, xanthan gum, aroma, sodium fluoride, sodium } \\
\text { saccharin, sucralose, titanium dioxide, sodium hydroxide, } \\
\text { limonene }\end{array}$ \\
\hline IK & Cocamidopropyl betaine & $\begin{array}{l}\text { Sodium fluoride } \\
500 \text { ppm }\end{array}$ & $\begin{array}{l}\text { Sorbitol, aqua, hydrated silica, aroma, cocamidopropyl betaine, } \\
\text { benzyl alcohol, carbomer, mica, sodium chloride, sodium } \\
\text { fluoride, sodium phosphate, sodium saccharin, trisodium } \\
\text { phosphate, xanthan gum, Cl16255, Cl77891 }\end{array}$ \\
\hline SK & Sodium lauryl sulfate & $\begin{array}{l}\text { Sodium fluoride } \\
500 \text { ppm }\end{array}$ & $\begin{array}{l}\text { Sorbitol, aqua, hydrated silica, PEG-32, sodium lauryl sulfate, } \\
\text { cellulose gum, sodium saccharin, sodium fluoride, mica, } \\
\text { calcium gluconate, tocopheryl acetate, glycerin, limonene, } \\
\text { phenylcarbinol, Cl12490, Cl77891 }\end{array}$ \\
\hline $\mathrm{OB}$ & Sodium lauryl sulfate & $\begin{array}{l}\text { Sodium fluoride } \\
500 \text { ppm }\end{array}$ & $\begin{array}{l}\text { Aqua, sorbitol, hydrated silica, sodium lauryl sulfate, cellulose } \\
\text { gum, aroma, sodium saccharin, carbomer, trisodium phosphate, } \\
\text { sodium fluoride, limonene, Cl42090 }\end{array}$ \\
\hline EL & Cocamidopropyl betaine, olaflur & $\begin{array}{l}\text { Aminfluorid } \\
500 \text { ppm }\end{array}$ & $\begin{array}{l}\text { Aqua, sorbitol, hydrated silica, hydroxyethylcellulose, } \\
\text { titaniumdioxide, cocamidopropyl betaine, olaflur, aroma, } \\
\text { limonene, sodium saccharin, hydrochloric acid }\end{array}$ \\
\hline EJ & Olaflur & $\begin{array}{l}\text { Aminfluorid } \\
1400 \text { ppm }\end{array}$ & $\begin{array}{l}\text { Aqua, hydrated silica, sorbitol, olaflur, hydroxyethylcellulose, } \\
\text { aroma, limonene, PEG-40 hydrogenated, castoroil, } \\
\text { titaniumdioxide, saccharin, hydrochloric acid }\end{array}$ \\
\hline
\end{tabular}

serum, penicillin (150 IU/mL), and streptomycin (150 $\mu \mathrm{g} / \mathrm{mL}$ ). The cells were then exposed to $100 \mu \mathrm{L}$ of toothpaste extracts, while the cell culture medium was used as a negative control. After $24 \mathrm{~h}$, cell survival was evaluated by assessing enzyme activity using 3-(4,5-dimethylthiazol-2-yl)-2,5-diphenyltetrazolium bromide (MTT). The cells were exposed to $200 \mu \mathrm{L}$ MTT solution $(0.5 \mathrm{mg} / \mathrm{mL})$ for $2 \mathrm{~h}$ at $37^{\circ} \mathrm{C}$. The blue formazan precipitate was then dissolved by shaking for $30 \mathrm{~min}$ at room temperature in $200 \mu \mathrm{L}$ dimethyl sulfoxide. Absorption was assessed using a spectrophotometer at $540 \mathrm{~nm}$ (BioTek Epoch, BioTek Instruments, Inc., Winooski, VT, USA). Three independent experiments were performed in four wells ( $n=12$ per group). Optical density readings from cultures exposed to extracts were compared with untreated control cells (100\%).

\section{Statistical Analysis}

The Shapiro-Wilk test was used to test the normal distribution of data. One-Way analysis of variance and Tukey's post-hoc test were used to compare cell survival ( $\alpha=0.05)$.

\section{Reactive Oxygen Species Measurements}

ROS levels were monitored using the oxidation-sensitive fluorescent probe 2'7'-dichlorodihydrofluorescein diacetate (H2DCF-
DA, Invitrogen Molecular Probes, Karlsruhe, Germany). Dichlorofluorescein, a non-fluorescent compound, is formed as a result of intracellular esterase activity. When oxidized, it converts to dichlorodihydrofluorescein diacetate (DCF-DA) and becomes fluorescent. L929 cells were seeded on each well of a 6 -well plate at a density of $2 \times 10^{5}$ cells/well and incubated at $37{ }^{\circ} \mathrm{C}$ for $24 \mathrm{~h}$. Thereafter, the cells were exposed to toothpaste extracts for $2 \mathrm{~min}$, with cells exposed to triethyleneglycol dimethacrylate (1 mmol/L TEGDMA, Sigma-Aldrich, Taufkirchen, Germany) as the positive control. Subsequently, L929 cells were incubated with $10 \mu \mathrm{M}$ H2DCF-DA at $37{ }^{\circ} \mathrm{C}$ for $30 \mathrm{~min}$. The cells were seperated using $0.05 \%$ trypsin/ethylenediamine tetraacetic acid and aggregated by centrifugation and washed with PBS. DCF fluorescence values were determined using flow cytometry (FACS Aria III, BD Biosciences, San Jose, CA, USA) at an emission wavelength of $519 \mathrm{~nm}$ and an excitation wavelength of $488 \mathrm{~nm}$ (FITC-1). The mean fluorescence values were obtained using histogram statistics (FACSDiva v6.1.3, BD Biosciences). Two wells were used in two independent experiments ( $n=4$ per group), and the results were averaged. All further analyses were performed using the averaged values. Differences in ROS levels were statistically evaluated 
Table 2. Effect of the original extracts and concentrations of pediatric toothpastes on the viability of L929 cells

\begin{tabular}{|l|l|l|l|l|l|l|}
\multirow{2}{*}{ Test groups } & \multicolumn{4}{l}{ Toothpaste concentration (Mean \pm SD) } \\
\cline { 2 - 7 } & $1: 1$ & $1: 2$ & $1: 4$ & $1: 8$ & $1: 16$ & $1: 32$ \\
\hline SP & $63.9 \pm 10.9^{\mathrm{aA}}$ & $81.1 \pm 7.9^{\mathrm{A}}$ & $82 \pm 5.6^{\mathrm{A}}$ & $103.4 \pm 51^{\mathrm{B}}$ & $107.6 \pm 4.3^{\mathrm{B}}$ & $111.9 \pm 10.2^{\mathrm{B}}$ \\
\hline IK & $84.3 \pm 14.2$ & $84.1 \pm 10.8$ & $89.7 \pm 15.3$ & $88.5 \pm 24.2$ & $90.9 \pm 14.6$ & $88.7 \pm 27.7$ \\
\hline SK & $7.6 \pm 1.1^{\mathrm{a}}$ & $8.0 \pm 0.6^{\mathrm{a}}$ & $8.3 \pm 1.1^{\mathrm{a}}$ & $8.4 \pm 1.5^{\mathrm{a}}$ & $10.8 \pm 1.9^{\mathrm{a}}$ & $26.2 \pm 5^{\mathrm{a}}$ \\
\hline OB & $10.8 \pm 1.3^{\mathrm{aA}}$ & $10.1 \pm 0.8^{\mathrm{aA}}$ & $17.1 \pm 3.1^{\mathrm{aA}}$ & $59.4 \pm 11.7^{\mathrm{aB}}$ & $93.2 \pm 8.4^{\mathrm{B}}$ & $96.9 \pm 4.4^{\mathrm{B}}$ \\
\hline EL & $102.7 \pm 4.0$ & $102.8 \pm 11.3$ & $96.9 \pm 10.0$ & $104.2 \pm 5.5$ & $85.0 \pm 7.4$ & $87.1 \pm 4.7$ \\
\hline EJ & $18.0 \pm 1.6^{\mathrm{aA}}$ & $40.4 \pm 7.2^{\mathrm{a}}$ & $52.1 \pm 8.8^{\mathrm{aB}}$ & $56.2 \pm 9.9^{\mathrm{aB}}$ & $61.1 \pm 18^{\mathrm{aB}}$ & $85.4 \pm 9.4^{\mathrm{B}}$ \\
\hline SP: & & &
\end{tabular}

SP: Sensodyne pronamel, IK: Ipana kids, SK: Signal kids, OB: Oral B, EL: Elmex, EJ: Elmex junior, SD: Standard deviation. Two min post-exposure was evaluated using the standard MTT assay. ${ }^{A, B}$ : Different upper-case superscript letters indicate a statistically significant ( $\left.p<0.01\right)$, a,b: Different lower-case superscript letters indicate a statistically significant $(p<0.01)$

Table 3. Generation of ROS in L929 cells after exposure to pediatric toothpastes

\begin{tabular}{|l|l|l|}
\hline & Mean & Standard deviation \\
\hline Negative control & 1.00 & 0.00 \\
\hline Positive control & 8.92 & 0.24 \\
\hline SP & $5.29^{n, p, a}$ & 0.49 \\
\hline IK & $5.23^{n, p, a}$ & 0.24 \\
\hline SK & $2.90^{n, p, b}$ & 0.31 \\
\hline OB & $2.42^{n, p, b}$ & 0.06 \\
\hline EL & $1.95^{n, p, b}$ & 0.03 \\
\hline EJ & $8.57^{n, p, b}$ & 0.01 \\
\hline
\end{tabular}

SP: Sensodyne pronamel, IK: Ipana kids, SK: Signal kids, OB: Oral B, EL: Elmex, EJ: Elmex junior, p: Significant difference from positive control group, $\mathrm{n}$ : Significant difference from negative control group, ${ }^{\mathrm{A}, \mathrm{B}}:$ Different upper-case superscript letters indicate a statistically significant $(p<0.01)$

using the Mann-Whitney $U$ test $(\alpha=0.05)$. Multiple comparisons were performed using the Bonferroni post-hoc test $(p<0.05)$.

\section{Results}

\section{Cytotoxicity of Pediatric Toothpastes}

Cell viability was significantly affected by the type and concentration (in ppm) of detergent (both $p<0.05$ ) in the toothpastes. The decrease in concentration from 1:1 to 1:32 decreased the cytotoxicity of toothpastes significantly $(p<0.05)$, except that of EL (Table 2$)$.

The effects of original extracts (1:1) and concentrations $(1: 2,1: 4,1: 8,1: 16$, and 1:32) of pediatric toothpastes on the viability of $L 929$ cells after 2 min of exposure were evaluated using the standard MTT assay. Varying degrees of cytotoxicity were determined from the experiments (Table 2).

The survival rates were significantly different between L929 cells exposed to 1:1 concentration of SP and cells in the negative control group $(p<0.05)$. There were no significant differences in the survival rates between $\mathrm{L} 929$ cells exposed to IK and EL and cells in the negative control group ( $p>0.05$ ). Significant differences were observed in the survival rates between the 1929 cells exposed to all concentrations of SK and cells in the negative control group $(p<0.05)$. However, significant differences were observed between cells in the negative control group and 1929 cells exposed to $1: 2,1: 4$, and $1: 8$ concentrations of OB $(p<0.05)$. Significant differences were observed in the survival rates between $L 929$ cells exposed to all concentrations of EJ (except 1:32) and cells in the negative control group $(p<0.05)$.

\section{Production of ROS by Pediatric Toothpastes}

ROS production was measured using the oxidationsensitive fluorescent probe H2DCF-DA. The L929 cell cultures were exposed to the toothpastes in the cell culture medium for $2 \mathrm{~min}$ and cell cultures exposed to $1 \mathrm{mmol} / \mathrm{L}$ TEGDMA were used as positive control. The mean fluorescence intensities were compared with those of untreated control cultures $(n=4)$. The amount of ROS was increased by approximately eightfold with $1 \mathrm{mmol} / \mathrm{L}$ TEGDMA. All toothpastes showed significant increase in the amount of ROS in 2929 cells $(p<0.05)$ (Table 3$)$. ROS values were significantly increased with SP, IK, SK, OB, EL, and EJ by 5.29, 5.23, $2.90,2.42,8.57$, and 1.95 -fold, respectively $(p<0.05)$.

\section{Discussion}

Biocompatibility is a unique property exhibited by a substance that interacts with its environment. The biological response of substances varies with changes 
in the host, method of substance application, or substance itself (12). When a specific biocompatible substance is applied to the host, the corresponding effect may be either cell damage or stimulation of the cellular synthesis of some proteins, leading to inflammation. The results of this study indicate the possibility of the contents of pediatric toothpastes to show toxic effects, which may increase in the presence of some ingredients, specifically SLS. Additionally, fluoride-rich toothpastes have toxic effects. In the current study, only SP and IK were not cytotoxic; other pediatric toothpastes showed cytotoxic effects on the L929 cells, partially proving our hypothesis.

Toothpastes and mouthwashes have been used for more than 3000 years and formulated to conceal malodor, remove tooth stains, and treat or prevent diseases of the teeth. The toothpastes generally contain detergents, foaming agents, preservatives, antimicrobial agents, moisturizers, and homogenizers. Each component has a specific function and provides different characteristics to the toothpaste $(2,13,14)$. The complete removal of products designed to expectorate after use is not possible, even for adults. Generally, it is more difficult in young children. Therefore, the frequent/daily use of toothpastes increases the necessity to investigate the potential systemic toxicity of their components (5).

There are many studies in the literature on the cytotoxicity of toothpastes $(9,15-17)$. Detergents, particularly SLS, have cytotoxic effects (9). The study of Cvikl et al. (9) was that SLS-and AF-containing toothpastes were more cytotoxic for $L 929$ fibroblast cells than CAPB and Steareth-20-containing toothpastes. In our study, all concentrations of SK containing SLS were cytotoxic to L929 cells. However, the 1:16 and 1:32 dilutions of OB containing SLS had no cytotoxic effects. Both these groups showed similar levels of ROS production. This result shows that cytotoxicity is affected by concentration.

Moore et al. (13) observed that detergents are associated with cell membrane disruption in vitro, a finding consistent with other in vitro studies; Cell incubation with SLS for 2 minutes reduces TERT-1 keratinocyte viability. Ghapanchi et al. (15) found that toothpastes containing SLS had various toxic effects on the primary epithelium and HeLa cells of the oral cavity. SLS showed the highest cytotoxicity at all timepoints in a study by Tabatabaei et al. (18).
Elevated ROS levels affect the redox biological signals that maintain the physiological functions (19). SLS may accelerate cell death and rapidly eliminate deleterious microorganisms from the population (20). SLS initially interacts with cell membranes, causing an increase in intracellular $\mathrm{Ca} 2+$. $\mathrm{Ca} 2+$ stimulates the secretion of IL-1 $\alpha$ due to calpain activation. IL-1 $\alpha$ also stimulates ROS formation (21).

ROS production in cells is an important determinant of cell damage or redox signaling (19). ROS production was high in non-cytotoxic groups showing that cell damage occurs even when the cell does not lose its viability. In this study, CAPB containing SP, IK, and EL showed high ROS levels. All these toothpastes contain different concentrations and types of CAPB and fluoride. SP and IK contain $1450 \mathrm{ppm}$ and 500 ppm sodium fluoride, respectively, and even 1:1 concentration of SP was cytotoxic. The difference between these two materials suggests that high doses of fluoride affect cell viability. Tabatabaei et al. (18) stated that the cytotoxicity of sodium fluoride was significantly correlated with time and increased over time. In other words, high concentrations for lesser durations and low concentrations for greater durations showed similar results.

The highest ROS level was found with EL containing 500 ppm AF, but EL containing 1400 ppm AF showed the lowest levels. This shows that low concentrations of AF leads to cell damage, even if the cell is alive. AF is also used as a detergent in toothpastes. Our results showed that all concentrations of EL and the 1:32 concentration of EJ were nontoxic. The determination of the most appropriate fluoride concentration for pediatric toothpastes requires comprehensive personalized evaluation after meticulous risk assessment. Toothpastes with lower fluoride concentrations can be recommended for children at risk of high fluoride toothpaste sensitivity (22). In general, children should brush their teeth twice a day using a fluoride and age-appropriate amount of toothpaste (23).

CAPB is also used as a detergent in toothpastes. No toxic effects were observed with any concentration of IK. Corroborating the results of our study, Cvikl et al. (10) proposed that children should only use CAPBcontaining dentifrices that are specially formulated for them. Despite its foaming ability, CAPB is less harmful than SLS (24). 
Recent studies on cell viability, cytotoxicity, and genotoxicity have revealed the potential adverse effects of toothpaste ingredients $(9,14,16)$. However, the conducive environment of the oral cavity differs from in vivo conditions, and many factors, such as saliva, mucus layer, creatinine levels, blood flow, and normal flora, can protect the oral environment from harmful effects $(15,16)$. Children older than six years have mixed dentition, and usually use adult dentifrices with higher fluoride concentrations and higher foaming properties, attributed to higher surfactant concentrations (1). This might explain the differing results for cell viability at varying ages after stimulation with toothpastes from the same manufacturer (10).

Further studies are needed to investigate the suitability of the oral cavity as a target tissue. Nonetheless, cell culture is an excellent method for assessing the mechanisms of incompatibility reactions. Alternatively, data from cytotoxicity tests, implantation studies, or cell culture models should be used to evaluate the biocompatibility of toothpastes.

\section{Conclusion}

Pediatric toothpastes containing sodium fluoride with SLS are more cytotoxic. AF-containing toothpastes with $1400 \mathrm{ppm}$ fluoride are more cytotoxic than with 500 ppm fluoride, but ROS levels are greater at 500 ppm fluoride. Toothpastes containing CAPB are less toxic.

\section{Ethics}

Ethics Committee Approval: This study was approved by the Selçuk University Faculty of Dentistry Ethics Committee (decision no: 2015/01, date: 08.10.2015).

Informed Consent: This study does not require patient consent.

Peer-review: Externally peer-reviewed.

\section{Authorship Contributions}

Design: F.K., H.E.Ü., Data Collection or Processing: F.K., Analysis or Interpretation: H.E.Ü., G.T., M.Ö., Literature Search: F.K., Writing: F.K., H.E.Ü., G.T., M.Ö.

Conflict of Interest: No conflict of interest was declared by the authors.

Financial Disclosure: The study was supported by scientific research coordinator of Selçuk University (project no: 16401027).

\section{References}

1. Stovell AG, Newton BM, Lynch RJ. Important considerations in the development of toothpaste formulations for children. Int Dent J 2013; 63 Suppl 2: 57-63.

2. Davies R, Scully C, Preston AJ. Dentifrices--an update. Med Oral Patol Oral Cir Bucal 2010; 15: e976-82.

3. Kanduti D, Sterbenk P, Artnik B. Fluoride: A Review of Use and Effects on Health. Mater Sociomed 2016; 28: 133-7.

4. Barnhart WE, Hiller LK, Leonard GJ, Michaels SE. Dentifrice usage and ingestion among four age groups. J Dent Res 1974; 53: 131722.

5. Schmalz G, Arenholt-Bindslev D, editors. Biocompatibility of dental materials (Vol 1). Berlin: Springer; 2009.

6. Souza-Rodrigues RD, Ferreira Sda S, D'Almeida-Couto RS, Lachowski KM, Sobral MÂ, Marques MM. Choice of toothpaste for the elderly: an in vitro study. Braz Oral Res 2015; 29: 1-7.

7. Kitchin PC, Graham WC. Sodium alkyl sulfate as a detergent in tooth paste. J Am Dent Assoc and Dent Cosmos 1937; 24: 73655.

8. Rantanen I, Tenovuo J, Pienihäkkinen K, Söderling E. Effects of a betaine-containing toothpaste on subjective symptoms of dry mouth: a randomized clinical trial. J Contemp Dent Pract 2003; 4: 11-23.

9. Cvikl B, Lussi A, Gruber R. The in vitro impact of toothpaste extracts on cell viability. Eur J Oral Sci 2015; 123: 179-85.

10. Cvikl B, Lussi A, Moritz A, Gruber R. Dentifrices for children differentially affect cell viability in vitro. Clin Oral Investig 2017; 21: 453-61.

11. Ray PD, Huang BW, Tsuji Y. Reactive oxygen species (ROS) homeostasis and redox regulation in cellular signaling. Cell Signal 2012; 24: 981-90.

12. Sakaguchi RL, Powers JM, editors. Craig's restorative dental materials-e-book. Elsevier Health Sciences; 2012.

13. Moore C, Addy M, Moran J. Toothpaste detergents: a potential source of oral soft tissue damage? Int J Dent Hyg 2008; 6: 193-8.

14. Bruno M, Taddeo F, Medeiros IS, Boaro LC, Moreira MS, Marques $\mathrm{MM}$, et al. Relationship between toothpastes properties and patient-reported discomfort: crossover study. Clin Oral Investig 2016; 20: 485-94.

15. Ghapanchi J, Kamali F, Moattari A, Poorshahidi S, Shahin $E$, Rezazadeh $F$, et al. In vitro comparison of cytotoxic and antibacterial effects of 16 commercial toothpastes. J Int Oral Health 2015; 7: 39-43.

16. Camargo SE, Jóias RP, Santana-Melo GF, Ferreira LT, El Achkar VN, Rode Sde M. Conventional and whitening toothpastes: cytotoxicity, genotoxicity and effect on the enamel surface. Am J Dent 2014; 27: 307-11.

17. Shahidi Z, Davani ST, Noori F, Tabatabaei MH, Sodeif F, Etemadi A, et al. Cytotoxicity and Antibacterial Activity of Toothpastes and Mouthwashes Available in the Iranian Market. Front Dent 2021; 18: 1-8.

18. Tabatabaei MH, Mahounak FS, Asgari N, Moradi Z. Cytotoxicity of the Ingredients of Commonly Used Toothpastes and 
Mouthwashes on Human Gingival Fibroblasts. Front Dent 2019; 16: 450-7.

19. Schieber M, Chandel NS. ROS function in redox signaling and oxidative stress. Curr Biol 2014; 24: R453-62.

20. Goldshmidt H, Matas D, Kabi A, Carmi S, Hope R, Michaeli S. Persistent ER stress induces the spliced leader RNA silencing pathway (SLS), leading to programmed cell death in Trypanosoma brucei. PLoS Pathog 2010; 6: e1000731.

21. Mizutani T, Mori R, Hirayama M, Sagawa Y, Shimizu K, Okano Y, et al. Sodium Lauryl Sulfate Stimulates the Generation of Reactive
Oxygen Species through Interactions with Cell Membranes. J Oleo Sci 2016; 65: 993-1001.

22. Kidd EA, Fejerskov O, editors. Dental caries: The disease and its clinical management. Blackwell Munksgaard; 2003.

23. Early Childhood Caries: IAPD Bangkok Declaration. Int J Paediatr Dent 2019; 29: 384-6.

24. Almohefer SA, Levon JA, Gregory RL, Eckert GJ, Lippert F. Caries lesion remineralization with fluoride toothpastes and chlorhexidine - effects of application timing and toothpaste surfactant. J Appl Oral Sci 2018; 26: e20170499. 